\title{
Genetically modified crops in Chile
}

\author{
Erika Salazar $^{1,2}$ and Gloria Montenegro ${ }^{3}$ \\ 'Ph.D. student in Agricultural Sciences Program in the Facultad de Agronomía e Ingeniería Forestal, \\ Pontificia Universidad Católica de Chile, Casilla 306-22, Santiago, Chile. \\ ${ }^{2}$ Centro Regional de Investigación La Platina, Instituto de Investigaciones Agropecuarias, Casilla 439-3 \\ Santiago, Chile. \\ ${ }^{3}$ Dirección de Investigación y Postgrado, Facultad de Agronomía e Ingeniería Forestal, Pontificia \\ Universidad Católica de Chile, Casilla 306-22, Santiago, Chile.
}

\begin{abstract}
E. Salazar, and G. Montenegro. 2009. Genetically modified crops in Chile. Cien. Inv. Agr. 36(3): 353-368. The economical, environmental and social impacts associated with genetically modified (GM) crops are supported by the increased use of GM species by farmers. This increase in the use of GM species has included a global increase in both the number of hectares with GM crops and the number of countries using this technology. However, the use of GM crops has some drawbacks, due to the environmental risks associated with some of the events and social risks related to intellectual property rights issues and the monopoly associated with this technology. An overview of the current status of the use of GM crops in relation to the production, benefits, associated risks, intellectual property rights, legislation and regulatory framework is presented, focusing in the situation of ties crops in Chile.
\end{abstract}

Key words: Genetically modified organisms, regulatory framework, intellectual property, Chile.

\section{Introduction}

In 1973, Stanley Cohen and Hebert Bouyer established the basis for what is known today as recombinant DNA technology. This technique allowed for genetic manipulation, in vitro handling of genes and, therefore, expanding the possibility for genetic exchange between living organisms, beyond the limits imposed by speciation (Cohen et al., 1973). This technology became part of what we now know as Modern Biotechnology, and was the starting point for the development of Genetic Engineering and

Received 12 June 2009. Accepted 22 September 2009.

Corresponding author: ersalaza@uc.cl its applications, which resulted in the development of a series of new products in such diverse sectors as medicine, agriculture, and mining. Consequently, in 1982, Genentech was able to produce recombinant human insulin, becoming the first commercial product of genes cloned in bacteria (Genentech, 2009).

Since 1986, the applications of modern biotechnology in the agricultural sector increased substantially and many different private companies involved in the genetic improvement of plants have introduced genetic engineering techniques into their programs, particularly in the USA. For example, Monsanto introduced Roundup Ready ${ }^{\circledR}$ soybeans, the first agricultural product to be genetically modified, to provide resistance to the herbicide glyphosate. In 1992, the first genetically modified crop, tobacco, was sold in 
China, although GM crop commercialization officially began in 1996 (Nap et al., 2003). In 1994, the first commercialization of a GM species began in the United States: Flavr-Savr ${ }^{\circledR}$, a slow-ripening tomato, produced by the antisense technique (Redenbaugh et al., 1992), and in 1995, the commercialization of canola resistant to the herbicide Basta (Gluphosinate ammonium) was approved (Cajacob et al., 2007). In England, Zeneca Plant Science commercialized the first food for consumption made with raw material from a genetically modified species. It consisted of a puree made from tomatoes which contained a modified polygalacturonase gene (Damen et al., 1997).

This first generation of transgenic plants focused on the introduction of traits that benefited farmers and included crops such as corn, soybeans and cotton. Genes conferring resistance to insects and tolerance to herbicides were introduced.

The introduction of new traits to improve the agronomic performance of the crops continues today, but a second generation of genetically modified crops is currently in development, including new traits to increase the quality and nutritive value of the crops, which will evidently benefit consumers. One example of these second generation GMOs is the "Golden Rice", which was developed by Swiss and German researchers who introduced the necessary genes to produce the metabolic route of beta carotene in rice endosperm, thus increasing its nutritional value (Ye et al., 2000). Other interesting traits currently being used include seeds with increased content of poly-unsaturated oils, foods that are more easily digestible, better quality foods, and fruits with longer postharvest lives. This technology is continually advancing and it is quite feasible that plants or animals could one day be used to create biofactories for producing specific biomolecules.

\section{Global status of the production and commercialization of genetically modified crops}

According to James (2007), crops from organisms produced by genetic engineering, now termed Genetically Modified Organisms (GMOs), offer solid and important economical, environmental and social benefits. These benefits are evident by the increased use of GMOs by farmers, since there are over 13,3 million farmers using GMOs in 2008. Likewise, an increase in the number of hectares destined for GMO crops in 2008 was recorded globally, reaching approximately 125 million of hectares, which was twice as much as in 2005 (Figure 1).

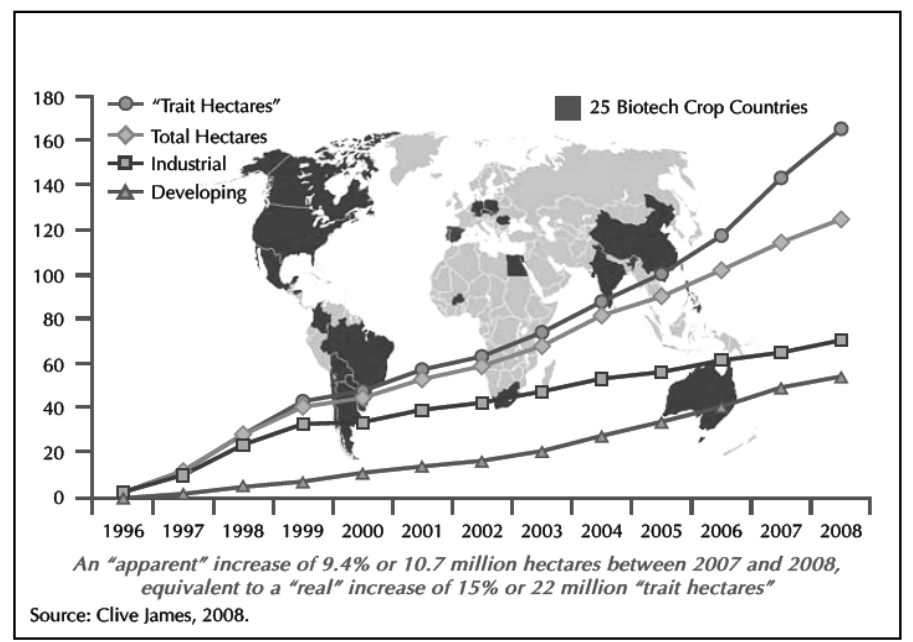

Figure 1. Global area of GM crops during the 1996-2008 period (million of hectares per trait). 
The number of countries and farmers adopting this new technology has also increased. It is noteworthy that in 2008, 25 countries introduced GM crops to their farms, setting a historical milestone. In 1996, the first year that GMOs were commercialized, only 6 countries were using this technology. This represented a $400 \%$ increase in only 13 years (Figure 1, Table 1). Of these 25 countries, 15 are developing countries. The number of countries using GMOs is predicted to increase to 40 by 2015 (James, 2008).

Table 1. Global areas of GM crops by country (millions of hectares).

\begin{tabular}{|c|c|c|c|}
\hline Ranking & Country & Surface & GM Crop \\
\hline 1 & * United States & 62,5 & Soy, corn, cotton, canola, pumpkin, papaya, alfalfa, beet \\
\hline 2 & * Argentina & 21,0 & Soy, corn, cotton \\
\hline 3 & * Brazil & 15,8 & Soy, corn, cotton \\
\hline 4 & * India & 7,6 & Cotton \\
\hline 5 & * Canada & 7,6 & Soy, corn, canola, remolacha \\
\hline 6 & * China & 3,8 & Cotton, tomato, petunia, papaya, pepper, álamo \\
\hline 7 & * Paraguay & 2,7 & Soy \\
\hline 8 & * South Africa & 1,8 & Soy, corn, cotton \\
\hline 9 & * Uruguay & 0,7 & Soy, corn \\
\hline 10 & * Bolivia & 0,6 & Soy \\
\hline 11 & * Philippines & 0,4 & Corn \\
\hline 12 & * Australia & 0,2 & Cotton, canola, clavel \\
\hline 13 & * Mexico & 0,1 & Cotton, soy \\
\hline 14 & * Spain & 0,1 & Corn \\
\hline 15 & Chile & $<0,1$ & Soy, corn, cotton \\
\hline 16 & Colombia & $<0,1$ & Cotton, clavel \\
\hline 17 & Honduras & $<0,1$ & Corn \\
\hline 18 & Burkina Faso & $<0,1$ & Cotton \\
\hline 19 & Czech Republic & $<0,1$ & Corn \\
\hline 20 & Romania & $<0,1$ & Corn \\
\hline 21 & Portugal & $<0,1$ & Corn \\
\hline 22 & Germany & $<0,1$ & Corn \\
\hline 23 & Poland & $<0,1$ & Corn \\
\hline 24 & Slovakia & $<0,1$ & Corn \\
\hline 25 & Egypt & $<0,1$ & Corn \\
\hline
\end{tabular}

* biotechnological Mega countries cultivating 50.000 or more hectares

Source: James, 2008.

According to James (2008), the most important factors associated with the impact of GMOs in recent years have been:

- The willingness of some African countries to use GMOs (South Africa, Burkina Faso and Egypt);

- Bolivia's decision in 2008 to authorize transgenic soybeans in order to increase the competitiveness of their crops with other producer countries such as Brazil and Paraguay, which have benefited for several years from soybeans tolerant to herbicides;

- The development of new varieties of GMOs by countries like Brazil (corn) and Australia (canola); 
- The development of a new GMO by the United States and Canada (beets); and

- The significant increase in the number of GMO varieties in crops, including those with more than one genetically modified trait. For example, crops have been engineered with simultaneous resistance to both herbicides and insects (e.g., corn and cotton).

It is expected that the use of varieties with stacked genetic modifications will increase. Of a total of 35.5 million hectares of corn cultivated in the United States, $85 \%$ are GMOs and $78 \%$ of these GMOs have more than one modified trait. SmartStax ${ }^{\mathrm{TM}}$ corn, which has eight genes for a number of different traits, is expected to reach the market by 2010. Similar modifications are occurring in cotton (James, 2008).

Table 1 shows that in 2008, the countries with largest area with GMOs cultivation were the USA, Argentina, Brazil, India, and Canada, which together represent $70 \%$ of the global use of GMOs.

According to James (2008), in 2008, soybeans were still the leading GMO crop, with 65.8 million hectares ( $53 \%$ of the total area), followed by corn (37.3 million ha), cotton (15.5 million ha) and canola (5.9 million ha).

Tolerance to herbicides continues to be the dominant trait used in GMOs, with $63 \%$ of the total area of GM crops with this trait (James, 2008; AGBIOS, 2009).

\section{Benefits of GMO technology}

As previously mentioned, the increased adoption of GMO technology at the global level is related to the economical, environmental and social benefits associated with this technology.

The benefits related to the use of GMOs in agriculture include increased crop productivity; higher income per cultivated area due to diminished production costs; a reduction in the application of pesticides; a decrease in plowing and the consequent reduction of soil erosion and the use of fuels; and a reduction in the emission of greenhouse gases, because of a higher carbon capture (Sasson, 2006; Cajacob, 2007).

As an example of the reduction of pesticide applications and emissions of greenhouse gases, Brookes and Barfoot (2006), analyzed the impact of the use of GMOs in 12 countries since 1996. They found a net economical benefit at the field level, which reached USD 5 billion in 2005 , with a total accumulation of USD 27 billion over a period of 10 years. Likewise, they indicate that the use of GMOs reduced the application of pesticides by 224 million kilograms, decreasing the impact of these products on the environment by $15 \%$. Finally, Brookes and Barfoot (2006) found that the use of GMOs reduced soil plowing and other farming activities, which caused a reduction in greenhouse gas emissions by the agricultural sector equivalent to removing 4 million cars from the market, in 2005.

At the global level, approximately 2 million people are susceptible to anemia due to iron deficiencies in their diets, and approximately 250 million people are exposed to xerophthalmia due to a lack of vitamin A. The nutritional quality of crops can be improved through genetic engineering which, along other strategies, can improve the nutritional level of the population, particularly in developing countries. Examples include the development of rice and mustard varieties rich in beta-carotene, and of potatoes and sweet potatoes with high protein content (Sasson, 2006).

This technology could potentially also be used to produce healthier foods. There is now the possibility of modifying the composition of oil fatty acids to become more polyunsaturated and to increase the content of antioxidants and vitamins. These changes could help to reduce the development of diseases such as cancer, hypertension, and heart disease (Yonekura-Sakakibara and Saito, 2006).

\section{GMOs and potential associated risks}

There is a general consensus that most of the applications of modern biotechnology in the in- 
dustry have a low level of risk for the environment because they are used in closed and controlled environments. However, in the case of crops and plantations, GMOs are developed in open spaces and thus exerting direct pressures on the natural environment and on traditional and organic agriculture.

Coner et al. (2003), Manzur (2005) and Sasson (2006) found that the following factors were the primary environmental risks associated with the release of GM crops in the field:

- Impacts on biodiversity, due to the possible exchange of genetic material by pollen flow between related species or by direct contact, in the case of bacteria. There is concern regarding the development of super weeds (wild species related to GM crops which may acquire genetic resistance to herbicides) and super plagues that are able to develop resistance to the toxins produced by the GM crop or that cause damage to the native insects as they eat toxins produced by a GM crop that are resistant to insects. These elements could change the balance of the ecosystems. There are several recent studies that have attempted to quantify the possible impacts of these factors, excluding the possible negative effects on biodiversity (Funk et al., 2006; Aono et al., 2006; Romeis et al., 2006). Regarding effects on biodiversity, Muñoz et al. (2004) designed a predictive model to assess the impact of GMOs on the Chilean native flora. When using this model, Prieto (2006) showed the introduction of GMOs in Chile, exhibit very low risk indexes.

- Environmentalcontaminationwithchemical products, because the use of agrochemical products will become massive, although fewer kilos of product per hectare of crops are used.

- Other biological contamination, such as the contamination on honey combs and honey itself with pollen from GMOs, which has already been reported (Bogdanov et al., 2003).

Wolfenbarger and Phifer (2000) compiled data from 35 scientific articles on the impacts of GMOs on the environment. These authors concluded that this small number of studies cannot provide enough information to determine whether the use of GMOs is ecologically risky or beneficial. The difficulty to answer these questions is mainly due to the complexity and diversity of the ecological systems being evaluated. Several authors have suggested the need for protocols to evaluate specific risks and to continue evaluations to determine the possible impacts of GMOs on organisms which are not the target of the GM crops (Schuler et al., 1999; Anklam et al., 2002; Dale et al., 2002; Dutton et al., 2003; Dunfield and Germida, 2004; O'Callaghan et al., 2005). Conner et al. (2003) have conducted extensive analyses and concluded that, in several cases, the ecological risk from the introduction of GMOs is not higher than the risk obtained from the introduction of a variety produced by conventional breeding.

In terms of risks to human health due to the consumption of "transgenic foods", the main concerns are allergies due to the possible production of allergenic proteins, the acquisition of resistance to antibiotics and possible toxic effects. Researchers have carried out a series of studies intended not only to answer these questions (Goldstein et al., 2005; Gay and Gillespie, 2005), but also to develop and evaluate a series of new techniques that, in the future, will replace the use of antibiotics as selection markers and will allow that gene to be withdrawn once the transformation is achieved (Hare et al., 2002; Goldstein et al., 2005; Wang, et al., 2005).

Transgenic crops intended for animal consumption and their potential impacts on human health are also important to consider (Kuiper et al., 2001; Dale et al., 2002, Nap et al., 2003, Manzur, 2005).

\section{GMO: International Regulatory Framework}

Although each country is free to establish its own biosafety standards, within the framework of the Convention of Biological Diversity at the global level, it was necessary to negotiate 
the first international agreement on biosafety, known as the Cartagena Protocol for the Safe Use of Biotechnology. This protocol entered into force on September $11^{\text {th }} 2003$, after being legally adopted (ratified) by 50 countries. The number of countries signing this protocol has increase to 156 to date (Convention on Biological Diversity, 2009). This protocol creates a regulatory framework intended to set an adequate level of safety on the transference, handling and use of GMOs in order to avoid possible adverse effects on the conservation and sustainable uses of biological diversity, also taking into account potential risks to human health. The Cartagena Protocol mainly focuses on the trans-border movement of GMOs (Sasson, 2006).

There are other international agreements and standards that include the use of GMOs, including the International Plant Protection Convention (IPPC) and the Codex Alimentarius Commission. These agreements discuss several aspects of safety with regards to GMOs and their derivatives.

Since 1970, several countries have established regulatory frameworks for the control of diverse biotechnology applications. Specifically, the efforts have focused on safety aspects of the application of this technology, and address impacts on humankind, animals and the environment (Nap et al., 2003). The regulatory system of the European Union comprises a series of resolutions, guidelines and amendments and includes several national committees and representatives. Guidelines 219/90 and 220/90 of the European Union are a group of standards for the release of GMOs into the environment that are aimed at regulating the processes of GMO production. On the contrary, the regulatory agencies of the USA (the top export country of genetically modified crops) consider these new genetic modification techniques to be an extension of other biotechnological processes. Thus, in the USA, the new products (GM plants) obtained through this technology are evaluated according to the same regulatory frameworks of risk assessment that were designed previously (Nap et al., 2003). There are three governmental agencies in the USA: agriculture, health and the environment, that work collectively on the regulation, field tests and control of the use of the "recombinant DNA technology". Therefore, the American regulation focuses mainly on the characteristics of the product, not on how it is produced. The criteria used by the European Guideline 220/90 and the American agencies of agriculture and health regarding human health and the environment are basically the same. The primary difference between these criteria is that the European agency sets the requirements to be fulfilled by the applicant for a field release, while in the USA, the criteria are basically formulated by the GMO generator, in agreement with the State agency.

Similarly, South American countries such as Brazil and Argentina have implemented traffic, seeding and GM material surveillance systems. In January 1995, Brazil published Law 8974 and Decree 1725/95, creating the National Technical BioSafety Committee (CTNBio), which is the governmental agency responsible for the regulations of GM plants in the field and for determining the standards for the use, content and release of GMOs into the environment. The Brazilian regulatory and functional framework is similar to the European scheme, as it considers the control of the recombinant DNA technology separate from that of other biological processes. However, from the point of view of the procedures of inspection and evaluation, Brazil follows the model implemented by the USA in which each authorization is followed by a critical local revision to ensure that the main measures of risk evaluation presented by the applicant are carried out correctly. Argentina defines the conditions that GMOs must fulfill before being used in the environment in Resolution 656 of the Secretariat for Agriculture, Livestock and Fisheries (SAGyP) from July 30, 1992 and in Resolution 837 of SAGyP from September 9, 1993, modified by Resolution 289/97 (Nap et al., 2003). These resolutions complement the existing regulations on agricultural protection (Decree Law of Agricultural Production Health Defense 6704/66), seeds and breeding (Law of Seeds and New Cultivars Creations 20247/73) and animal health (Law of Veterinary Products). Like Brazil, the Argentinean strategy 
is based on the approval for release in the field (Flint et al., 2000) and is based on similar transgenic events to those that are being approved in Europe, in order to not affect the strong export position of the country.

\section{GMO and Protection of Intellectual property}

The public perception and social acceptance of products derived from biotechnology are highly influenced by the debate that has arisen from GMO patenting and more broadly from the possibility of patenting life. This complements the concern from consumer associations and antiglobalization groups regarding the dominance of private corporations from developed countries in terms of patents registrations, which negatively impacts and deepens the social and economical differences in developing countries (Sasson, 2006).

The detractors argue that patenting and intellectual property protection is in conflict with the free exchange of human knowledge, depriving mankind from the benefits of science; delaying or increasing the price of the dissemination of knowledge; hindering the adoption of this knowledge; or focusing investigations on profitable issues that only benefit some people rather than on topics that are relevant to the whole society, which, undermines society's trust in science (Boettiger and Chi Ham, 2007). Furthermore, people in favor of patenting GMOs argue that patenting and protection of intellectual property are important mechanisms to ensure a fair retribution to the institutions for their investments in the development of new knowledge and technologies. In addition, supporters argue that patenting promote innovations and is a source of income for research centers, thus promoting collaboration between science and industry (Mahoney and Krattiger, 2007).

The sequencing of a growing number of genomes from diverse species contributes to a deep understanding of how life develops and evolves (NCBI, 2009). The amount of genetic information available has highlighted the complex matter of property of genomic information, as well as the ethical and legal implications of that property. In general, the patent systems in most of the countries do not explicitly exclude the possibility of patenting the genetic material. Thus, if a gene or DNA fragment fulfills the requirements of being novel, inventive and has industrial applications or utility, a patent may be granted. The core discussion in several countries is whether genes or parts of genes should be considered to be inventions or only new discoveries. Genes, genetic information or sequences are feasible to be patent in the USA and countries that are members of the European Community, if the genes or sequences can be attributed some kind of industrial or use applicability, which must be proved. The low levels of requests of these countries in terms of industrial applicability verification; their dominance regarding patenting at the global level; and the huge opportunities offered by genomics and genetic information have caused several countries and organizations to question whether living organisms and their parts can be patented. The proposals of different countries and organizations range from abolishing the right to patent living organisms or their parts to reducing the registration period, allowing biotechnological processes to be in the public domain more quickly.

\section{Chilean status}

In Chile, GMOs have been cultivated since 1987, when the first field releases were authorized for experimental purposes (James and Krattiger, 1996). Since 1992, crops were authorized in the country exclusively for the production of export seed. Corn, canola and soybeans are the main GM crops grown in the country (Table 2). Table 3 shows the total number of GM plant species that have been cultivated in recent years, a figure that has varied between 9 and 11 species, depending on the year. In 2007, the area with for GM crops exceeded 20,000 hectares (SAG, 2009).

In the period from 2007 to 2008 , the Chilean seed export market was USD 240 million, of which USD 190 million corresponded to GM varieties. 
Table 2. Increases in the area of the main GM crops exported from Chile (hectares).

\begin{tabular}{cccccccccc}
\hline Crop & $2002 / 03$ & $2003 / 04$ & $2004 / 05$ & $2005 / 06$ & $2006 / 07$ & $2007 / 08$ & $2008 / 09$ & Total \\
\hline Corn & 10.400 & 8.450 & 7.614 & 12.120 & 17.981 & 21.830 & 20.977 & 99.372 \\
Canola & 110 & 140 & 746 & 628 & 444 & 1.188 & 4.011 & 7.267 \\
Soy & 215 & 128 & 273 & 166 & 250 & 1.397 & 5.389 & 7.818 \\
Total & 10.725 & 8.718 & 8.633 & 12.914 & 18.675 & 24.415 & 30.377 & 114.457 \\
\hline
\end{tabular}

Source: SAG, 2009.

Table 3. Area of transgenic crop species during the 2008-2009 season (hectares).

\begin{tabular}{|c|c|c|c|}
\hline Species & Region & Total per Region & Total per species \\
\hline & Metropolitana & 0.0816 & \\
\hline & Bío Bío & 0.0816 & \\
\hline \multirow[t]{8}{*}{ Alfalfa } & La Araucanía & 0.05 & 0.2132 \\
\hline & Arica and Parinacota & 0.03 & \\
\hline & Metropolitana & 80.114 & \\
\hline & O’ Higgins & 5.52 & \\
\hline & Maule & 244.9 & \\
\hline & Bío Bío & 698.3 & \\
\hline & La Araucanía & $2,174.25$ & \\
\hline & Los Ríos & 758.5 & \\
\hline Canola & Los Lagos & 50 & $4,011.61$ \\
\hline Cartamo & Metropolitana & 65 & 65 \\
\hline \multirow[t]{8}{*}{ Cebada } & La Araucanía & 0.7 & 0.7 \\
\hline & Arica and Parinacota & 52.4 & \\
\hline & Valparaíso & 249.061 & \\
\hline & Metropolitana & $2,208.78$ & \\
\hline & Maule & $12,138.93$ & \\
\hline & O'Higgins & $6,317.22$ & \\
\hline & La Araucanía & 1 & \\
\hline & Bío Bío & 9.52 & \\
\hline Corn & Los Ríos & 0.3 & $20,977.21$ \\
\hline \multirow[t]{8}{*}{ Beet } & Bío Bío & 1.712 & 1.712 \\
\hline & Arica and Parinacota & 0.48 & \\
\hline & Coquimbo & 156.2 & \\
\hline & Valparaíso & 288.805 & \\
\hline & Metropolitana & 593.92 & \\
\hline & O'Higgins & $1,566.15$ & \\
\hline & Maule & $2,665.52$ & \\
\hline & Bío Bío & 102 & \\
\hline Soy & La Araucanía & 16 & $5,389.08$ \\
\hline Tomato & Valparaíso & 0.3 & 0.3 \\
\hline Vid & Metropolitana & 1 & 1 \\
\hline Zapallo & Metropolitana & 0.22 & 0.22 \\
\hline total Surface & & & $30,447.04$ \\
\hline
\end{tabular}

There has been limited research in GMOs in Chile. Most studies have been focused on a few forest species (pine, eucalyptus, poplars) and in some agricultural species (potatoes, melons, grapes and peach trees).
There are still crucial matters pending for the proper development of this new technology in Chile. Biosafety and access to genetic resources are two of the most important ones which require proper regulation. Despite that 
the Chilean State understands the potentiality of these technologies for the future of humanity and that although it has supported research and development of biotechnology, including transgenics, there is still room for improvement if Chile is committed to be competitive in the agricultural and agrifood world. Since 1998, funds for transgenic projects has increased continuously, which reflects the important support of the government for this activity. The implementation of several programs, including the following, has helped to support the investigation in this area: the Program of Development and Technological Innovation from 2001-2006 (Ministry of Economy, 2005); the implementation of the National Policy of Biotechnology, launched in November of 2003 (Government of Chile, 2005); and the activities included in the Genoma Chile Initiative. Thus, in 2002, approximately USD 7.5 millions were allocated to finance 16 projects, including transgenics and related disciplines (Manzur, 2003). The Instituto de Investigaciones Agropecuarias, Pontificia Universidad Católica de Chile and Universidad de Talca are the most active institutions in this field. Other institutions which have developed or are developing projects with GMOs and related disciplines are the Universidad de Chile, Fundación Chile, the Universidad de Santiago, the Universidad Técnica Federico Santa María, the Universidad Católica del Norte, the Universidad de Antofagasta, the Centro de Estudios Científicos de Valdivia and Vitrogen S.A. (Manzur, 2003).

Up to 2002, genetic modification of the following 17 organisms were carried out in Chile: 2 species of bacteria (Erwinia and Thiobacillus ferrooxidans), 10 crops (potato, corn, tomato, sugar crane, grape, melon, apple, wheat, peaches, and apricots), 1 ornamental species (Rodophiala) and 2 forest species (pine, eucalyptus). The search for resistance to biotic factors such as insects, viruses, bacteria, fungi and nematodes constitute the biggest efforts (Manzur, 2003). In addition, studies on the development of varieties that are tolerant to abiotic stress, such as salinity, drought and cold have been included in recent years, as have studies aiming to improve organoleptic and long shelf life traits of some fruit species.
Between 2003 and 2007, the Chilean State financed 35 biotechnology projects that were focused on the Chilean fruit sector. Sixteen private companies and 19 public institutions were funded to conduct research projects. Main research areas include genomic, genetic engineering and breeding programs for introducing resistance to abiotic factors (e.g., salinity) and improving quality, and genetic identification and GMOs traceability. These efforts were mostly into 3 species: grapes, citrus and stone fruits (peach and nectarines). The leaders in these research areas are the Instituto de Investigaciones Agropecuarias (7 projects); the Universidad de Chile (3 projects); the Pontificia Universidad Católica de Chile (2 projects); the Universidad Técnica Federico Santa María (2 projects); and the Universidad Austral de Chile (2 projects) (Ideaconsultora, 2008).

Some outstanding projects under development by public institutions are being conducted by the Instituto de Investigaciones Agropecuarias with the support of Consorcio BioFrutales S.A. These projects focus on the development of grapes resistant to fungal diseases (Botrytis and oidium); peaches and nectarines resistant to viral diseases, physiological fruit disorders (mealiness) and long postharvest life. In collaboration with the Instituto Forestal, they are carrying out studies on the development of Eucalyptus varieties tolerant to drought. The Pontificia Universidad Católica de Chile is currently working on the development of citrus species resistant to drought and tolerant to nitrogen deficiency; the development of potatoes resistant to viruses; and the development of Pinus radiata resistant to the Pine Shoot moths and tolerant to glyphosate (Ideaconsultora, 2008).

The products obtained in studies by the Instituto de Investigaciones Agropecuarias include the obtention of specific genes increasing tolerance to fungi; transgenic lines of rootstocks with resistance to the Grapevine fanleaf virus (GFLV); and tablegrapes with tolerance to Botrytis and powdery mildew. In stone fruits, a transformation platform was developed for Japanese Plums (Prunus salicina) to confer resistance to Plum Pox Virus (PPV), and for the first time ever, for peach trees (Prunus persica) (Prieto and Muñoz, 2009). 


\section{Protection of Intellectual property in Chile}

In Chile, Law 19.039 of 1991 of Industrial Property, with amendments in 2005 (by Law 19.996), and 2007 and Act 19.996, which states that the requirements for patentability are in place for Intellectual Property Protection. This law establishes the protection of the biological and genetic patrimony, as well as the traditional national knowledge, and allowing the granting of Industrial Property Rights. Under this law, plants, animals and procedures for plant and animal breeding, because of their essentially biological nature are not considered to be inventive and, therefore, are excluded from protection. The microorganisms and microbiological procedures satisfying the general requirements of the registration process may be protected with this law.

Likewise, are excluded from patenting parts of living organisms, as they are found in nature; natural biological processes; biological material existing in nature or materials that may be isolated from natural organisms. However, procedures using one or more of the biological materials mentioned before, and the products obtained directly from these products, may be protected, as long as they satisfy the requirements established in Article 32 of the current law, specifying that biological materials must be properly described and the industrial application of the same material must be explicit in the patent application (article 37f).

With regard to the protection of plant varieties, the Agreement on Trade-Related Aspects of Intellectual Property Rights (TRIPS), ratified by Chile in 1994, obliges all of the members of the World Organization to implement minimum standards for the protection of intellectual property rights. In this Agreement, microorganisms are protected by registration. The agreement allows the option to protect new plant varieties either through plant patents or through effective sui generis systems. Chile opted for the last system as defined in the Law 19.342 of 1994 for Plant Breeder Rights of New Varieties, and Decree Law 1764 that regulates the on seed industry in Chile. This law allows the conferment of Intellectual Property Rights on varieties of all botanic species. It contemplates both the so called Plant Breeder's Right, which authorizes the use of the protected material for breeding new varieties and the so called Farmer Rights, which authorizes the use of protected materials for its own use but prohibits its commercialization to third parties; provides the possibility of obligatory licenses in cases of public interest; and establishes the Servicio Agrícola y Ganadero as the competent body to determining the effects of the law (Pardo, 2006).

\section{Current status of National Regulatory Framework regarding GMOs}

The introduction of GMOs to productive activities requires that the systems for risk assessment be reformulated in accordance with international agreements, to cover both their effects on biodiversity and on human health (these systems are commonly known as biosafety systems). In the current context, the Chilean policy should consider various international Agreements, which involves the signing, ratification and, finally, the fulfillment of the obligations undertaken with the World Commerce Organization, the Codex Alimentarius, the Cartagena Protocol and the Convention of Biological Biodiversity. As of 2009, neither the Cartagena Protocol nor the Convention de Biological Diversity has been ratified.

In the absence of a specific regulation on biosafety and due to the pressure derived from the rise of GMOs at the global level, the Chilean State regulated the field release of GMOs based on existing laws as the Law that regulates the Seed Industry and the General Phytosanitary Law. The first specific regulation, with regard to GMOs in Chile, was the Exempt Resolution 1927 of 1993 which regulated the release of transgenics to the environment (field Releases), dictated by the Servicio Agrícola y Ganadero (SAG), based on Decree of the General Phytosanitary 3557. Under this resolution, risk assessment evaluation is conducted in Chile by an Advisory Committee for the Release of Transgenics (CALT), belonging to the SAG. The eval- 
uation of CALT is based on an affidavit, completed by the applicant, regardless of whether they are an importer or a plant breeder of a GM crop. A complete description of the diverse botanical, agronomic and molecular components of the new crop is written in this form. Applications of the GMOs developed in Chile, are willfully subject to CALT, but so far, all transgenics developed in Chile have requested a permit to make the release (Pardo, 2006).

Risk assessment studies should be included in the documents that accompany the application to the CALT. These studies should evaluate the possible environmental interactions and propose methods to control a potential genetic flow of transgenic gametes. Permits are only granted for research purposes and, in the case of commercial production, the transgenic seed must be re-export, except in the specific case of the corn resistant to glyphosate, gluphosinate ammonium and with Bt protein (Lepidopthera) for animal consumption, according to the Exempt Resolution 3970 of 1998, SAG. According to this decree, the entrance of GM seed into Chile is only authorized for seed production and exportation; growing GM crops for human consumption is not allowed; feeding animals with GMO is permitted, while the production of GM crops for personal consumption is not allowed; therefore, even the GM crops used for animal feeding must be imported.

Resolution 1523 of July 2001, updates the Regulatory Standards for the introduction of GMO to Chile and their release to the Environment. The regulation also covers biosafety measures, including shelter sites for GM crops for resistance to pests, and particularly rules the case in which of transgenic crops are intended to be released in areas where center of origin of some species are located. In addition, the introduction of transgenic products to the country requires that the products have received a favorable release report from the country where the transgenic was originally developed indicating that the released event did not produced any adverse effects on the environment (Pardo, 2006).

Resolution 3970/97 authorizes the consumption of animal feed with transgenic corn grain with the following genetic modifications: resistance to the herbicides glyphosate and gluphosinate ammonium; resistance to lepidopterans; and decreases in effects on male sterility. This resolution only involves biotechnological events approved for animal and human consumption in the country of origin or another country (Pardo, 2006).

It is important to note that both the CALT and the Technical Secretarial Office of SAG were created by Resolution 269 of 1999. This committee underwent further modifications during its conformation (resolutions 1495 of 2000 and 1655 of 2000). All of these resolutions were consolidated in Resolution 2004 of 2000, through which the CALT and the Technical Secretarial Office were created to decide on the introduction of an OGM to the environment. This resolution was confirmed by Resolution 6966 of 2005, through which the GMO Technical Committee and its Technical Secretarial Office were created.

In summary, SAG is the institution that authorizes and make sure that the applicant complies with the biosafty regulations.

The Ministry of Health, is responsible for regulating matters related to the health of the people consuming GMO or GMO derived products. On January 13, 2000, presented a modification to the Sanitary Act stating that, for GMO consumption, the release risk analyses should be conducted on a case by case. The prohibition of the use of transgenic ingredients in children's foods was derogated in 2003 by this Ministry. Currently, Ministry of Health is the entity regulating and authorizing the use of GMO raw materials in foods. By mid-2006, it began to elaborate a standard for the evaluation and authorization of transgenic foods in Chile, expressed in Resolution 83 from 2007.

Likewise, the regulation regarding the consumption of foods in Chile is found within the Law of Consumers Rights. This law explicitly recognizes the rights of consumers to compulsory labeling, but this aspect does not apply to 
transgenic products and is not included in the National Biotechnology Policy.

Regarding transgenic organisms in confined environments, the National Commission of Scientific and Technological Research, CONICYT, created a Subcommittee of Biosafety within the National Committee of Biotechnology in 1992, which elaborated the Manual of Biosafety Standards in 1994 for the creation of transgenic organisms in the laboratory and for their intentional release in the environment, but this are guidelines with no legal effects. This manual is applied willfully.

On November 30, 2000, the creation of the International Advisory Committees on Environmental Matters was published in the Official Journal, including the National Committee for Biosafety Matters. The National Commission of the Environment (CONAMA) and the Ministry of Foreign Affairs are currently tracking international discussions on the Protocol de Cartagena on Biotechnology Safety.

Finally, within the framework of Law 20116 and the Supreme Decree 320, the Subsecretary of Fisheries is the governing body in charge of the regulation, evaluation and authorization of the use of aquatic GMOs (plants or animal). To date, neither of these types of GMOs are produced or sold in the country.

\section{National Policy for Biotechnology Development}

The National Policy of Biotechnology (Government of Chile, 2005), launched in November of 2003 and currently implemented by the Ministry of Economy, intends to coordinate the state's efforts regarding biotechnology applied to the agricultural, forest and aquaculture sectors.

In 2004, the Ministry of Economy, along with other public services, began its first effort to produce a law proposal on the Biosafety of Genetically Modified Organisms, which is still pending. On the other hand, in 2005 CONAMA completed a new proposal on biosafety, which is part of a world initiative from the United Nations to correctly implement the Cartagena Protocol and is intended to support developing countries (Biosafety Chile, 2009).

Chile has developed several different efforts to establish a clear regulatory framework for biosafety. However, there is no available framework that satisfies the multiple requirements for the development of biotechnology as a productive business in Chile.

\section{The future of GMOs}

There seems to be a general consensus that genetic engineering will be a widely applied technology in the future, not only because of the potential of the technology itself, but also because a lot of efforts are being made to understand the ways in which genes control each trait observed in living organism. In doing this a series of new technologies has arise such as genomics, transcriptomics, proteomics and metabolomics, whose objectives are to identify the genes responsible for each trait in an individual and to determine how these traits are regulated. Therefore, in addition to the study of gene expression at the ARN level, or at the expression of specific metabolites, procedures that could be developed to further determine the levels of GMO Safety (Nap et al., 2003). In this way, the main limitations of transgenics --that is, the availability of genes for use in genetic transformation-- will be solved. Currently, the genes available for transgenisis in plants, for example, are less than 100, but it is predicted that in the near future, this availability will increase dramatically. This increased availability of genes will occur when the cost of technologies, such as sequencing, decreases, when databases containing this information grow considerably, and when the development of technologies such as bioinformatics enables these genes to be systemized and used.

This review seems to indicate that the benefits derived from the use of this technology are so 
dramatic that very few will resist its adoption. As mentioned previously, this technology has been adopted in several places and by several farmers over a very short time period. Therefore, for some species and some countries, nearly the entire production of particular crop will be based on GMO varieties. That is the case, for example, for corn in the USA.

Another important consideration deals with how science and technology have developed methods allowing the risks from some GMOs to be minimized. Nowadays, very few people question the safety of GMO-derived foods for human and animal consumption, which was not the case when GMOs were first commercialized. More than 10 years after humans and animals have been consuming transgenic foods without any serious incidents of intoxication or damage, the discussion on the potential harmful effects has focused more on environmental aspects than on the potential negative effects on human health.

Regarding scientific advances, it is evident that progress has been made in the development of techniques that minimize environmental risks. In the near future, antibiotics will rarely be used as marker genes and only those technologies allowing the insertion of genes that codes for the trait being introduced will be widely used. On the other hand, technologies such as gene silencing have been developed (Sanders and Hiatt, 2005), which consists of hindering the expression of genes present in a plant genome. This and other technological innovations have initiated the so-called fields of cisgenics and intragenics (Schouten and Jacobsen, 2008). Both techniques minimize the environmental risks because only genes existing in the plant or in the same species are used during the process of generating a new variety.

The information reviewed in this paper suggests that genetic engineering in plants will become a widely used technology and that Chile should stay current with this developing technology. National research must continue to be competitive since this technology offers real opportunities for the development of agriculture and forests in the country. However, before this technology is widely accepted by the Chilean society, a national legislation and a regulatory framework must be implemented to guarantee safe and effective production and to minimize the negative effects of GM crops on the environment. The establishment of regulations related to traceability and the labeling of raw materials and food products are also important matters.

\section{Acknowledgment}

The authors are grateful for the review and input to the paper made by Dr. Carlos Muñoz Schick from the Instituto de Investigaciones Agropecuarias (INIA) - CRI La Platina, Santiago, Chile. 


\title{
Resumen
}

\begin{abstract}
E. Salazar y G. Montenegro. 2009. Cultivos genéticamente modificados en Chile. Cien. Inv. Agr. 36(3):353-368. Los beneficios económicos, ambientales y sociales asociados al cultivo de especies genéticamente modificados (GM) se ven respaldados por la creciente adopción de éstos por parte de los agricultores los que ha significado, a nivel mundial, un incremento importante tanto en el número de hectáreas destinadas su cultivo como en el número de países que utilizan esta tecnología. El uso de cultivos GM no ha estado exento de detractores, no sólo por la posibilidad de riesgo tanto al medio ambiente como a la salud humana, sino porque la investigación y desarrollo está basada fuertemente en el patentamiento y la protección de la propiedad intelectual. Este trabajo presenta una reseña general del estado actual del uso de cultivos GM en relación a la producción, beneficios y riesgos asociados, derechos de propiedad intelectual, legislación y marcos regulatorios, enfocado principalmente a la situación de estos cultivos en Chile.
\end{abstract}

Palabras clave: Organismos genéticamente modificados, marco regulatorio, propiedad intelectual, Chile.

\section{References}

AGBIOS. 2009. GM database. Available online at: http://www.agbios.com/dbase.php

Anklam, E., F. Gadani, P. Heinze, H. Pijnenburg, and G. Van Den Eede. 2002. Analytical methods for detection and determination of genetically modified organisms in agricultural crops and plantderived food products. European Food Research and Technology 214(1):3-26.

Aono, M., S. Wakiyama, M. Nagatsu, N. Nakajima, M. Tamaoki, A. Kubo, and H. Saji. 2006. Detection of feral transgenic oilseed rape with multiple-herbicide resistance in Japan. Environ. Biosafety Res. 5: 77-87.

BioSeguridadChile, 2009. Available online at: www. bioseguridadchile.cl

Boettiger, S., and C. Chi-Ham. 2007. Defensive Publishing and the Public Domain. In: Krattiger A., R.T. Mahoney, L. Nelsen, J.A. Thomson, A.B. Bennett, K. Satyanarayana, G.D. Graff, C. Fernandez, and S.P. Kowalski (eds). 2007. Intellectual Property Management in Health and Agricultural Innovation: A Handbook of Best Practices. MIHR: Oxford, U.K., and PIPRA: Davis, California, USA. Available online at: www. ipHandbook.org

Bogdanov, S., A. Imdorf, V. Kilchenmann, J.D. Charriere, and P. Fluri. 2003. The contaminants of the bee colony. Apiacta 38, 1-14.

Brookes, G., and P. Barfoot. 2006. Global Impact of
Biotech Crops: Socio-Economic and environmental effects in the first ten years of commercial use. AgBioForum 9(3): 139-151

Cohen, S.N. Chang, A. C. Y., Boyert, H. W., and Helling, R. B. 1973. Construction of biologically functional bacterial plasmids in vitro. Proc. Nat. Acad. Sci. USA. 70 (11): 3240-3244.

Conner, A. J., T.R. Glare, and J.P. Nap. 2003. The release of genetically modified crops into the environment. Part II. Overview of ecological risk assessment. The Plant Journal 33: 19-46.

Convention on Biological Diversity. 2009. The Cartagena Protocol con biosafety. Available online at: http://www.cbd.int/biosafety/

Cajacob, C.A., P.C.C. Feng, S. Reiser, and S.R. Padgette. 2007. Genetically modified herbicide resistant crops. In: Modern Crop Protection Compounds. Krämer W. and U. Schirmer. (eds). WILEY-VCH Verlag GmbH and Co. KGaA, Weinheim. 1394 p.

Dale, P.J., B. Clarke, and E.M.G. Fontes. 2002. Potential for the environmental impact of transgenic crops. Nature Biotechnology 20:567- 843.

Damen V., C. Adley, F. Brinkman, D. Hammenlev, M. Jihansson, M. van Strydonk. 1997. Transgenic plants. European Initiative for Biotechnology Education. Available online at: www.reading. ac.uk/NCBE

Dunfield, K.E., and J.J. Germida. 2004. Impact of Genetically Modified Crops on Soil- and PlantAssociated Microbial Communities. J. Environ. Qual. 33:806-815. 
Dutton, A.R., J. Romeis, and F. Bigler. 2003. Assessing the risks of insect resistant transgenic plants on entomophagous arthropods Bt-maize expressing $\mathrm{Cry} 1 \mathrm{Ab}$ as a case study. BioControl 48: 611-636.

Flint, J., L. Gil, J. Verastegui, C. Irarrazabal, and J. Dellacha. 2000. Biosafety information management systems. A comparative analysis of the regulatory system in Canada, Argentina and Chile. EJB Electronic Journal of Biotechnology 3(1):9-29.

Funk, T., G. Wenzel, and G. Schwarz. 2006. Outcrossing frequencies and distribution of transgenic oilseed rape (Brassica napus L.) in the nearest neighbourhood. European Journal of Agronomy 24(1): 26-34.

Gay, P. and S. Gillespie. 2005. Antibiotic resistance markers in genetically modified plants: a risk to human health? The Lancet Infectious Diseases 5(10):637-646.

Genentech. 2009. First Successful Laboratory Production of Human Insulin Announced. Available onlineat:http://www.gene.com/gene/news/pressreleases/display.do?method=detail\&id $=4160$.

Goldstein D.A., B. Tinland, L.A. Gilbertson, J.M. Staub, G.A. Bannon, R.E. Goodman, R.L. McCoy, and A. Silvanovich. 2005. Human safety and genetically modified plants: a review of antibiotic resistance markers and future transformation selection Technologies. Journal of Applied Microbiology 99: 7-23.

Gobierno de Chile. 2005. Política nacional para el desarrollo de la biotecnología. Avances 20032005. Santiago, Chile. 55 p.

Hare P.D., and N.H. Chua. 2002. Excision of selectable marker genes from transgenic plants. Nat. Biotechnol. 20: 575 - 580 .

Ideaconsultora. 2008. Desarrollo de Capacidades humanas especializadas en biotecnología en Chile para el desarrollo de una fruticultura competitiva. Taller de Articulación en Vinculación Ciencia_Empresa. Organizado por Ideaconsultora. Santiago, Talca y Valparaíso, 12-14 de mayo de 2008.

James, C. 2007. Global status of commercialized biotech/GM crops:2007. ISAAA Brief $\mathrm{N}^{\circ} 37$. ISAAA: Ithaca, NY.

James, C. 2008. Global Status of Commercialized Biotech/GM Crops: 2008. ISAAA Brief No. 39. ISAAA: Ithaca, NY.

James, C., and A.F. Krattiger. 1996. Global Review of the Field Testing and Commercialization of
Transgenic Plants, 1986 to 1995: The First Decade of Crop Biotechnology. ISAAA Briefs No. 1. ISAAA: Ithaca, NY. pp. 31.

Kuiper, H.A., G.A. Kleter, H.P.J.M. Noteborn, and E.J. Kok. 2001.Assessment of the food safety issues related to genetically modified foods. Plant J. 27: 503-528.

Mahoney, R.T., and A. Krattiger. 2007. The role of IP management in health and agricultural innovation. In: Krattiger A., R.T. Mahoney, L. Nelsen, J.A. Thomson, A.B. Bennett, K. Satyanarayana, G.D. Graff, C. Fernandez, and S.P. Kowalski (eds). 2007. Intellectual Property Management in Health and Agricultural Innovation: A Handbook of Best Practices. MIHR: Oxford, U.K., and PIPRA: Davis, California, U.S.A. Available online at: www.ipHandbook.org

Manzur, I. 2003. Investigación biotecnológica en Chile orientada a la producción de transgénicos. Fundación Sociedades Sustentables, Santiago, Chile, $80 \mathrm{p}$.

Manzur, I. 2005. Biotecnología y bioseguridad: La situación de los trangénicos en Chile. Fundación Sociedades Sustentables, Santiago, Chile, 119 p.

Ministerio de Economía. 2005. Innovar en Chile. Programa de desarrollo e innovación tecnológica 2001-2006. Santiago. 120 p.

Muñoz, C., H. Prieto, P. León, E. Salazar, F. Reyes, M. Rosas, and M. Muñoz. 2004. Diagnóstico sobre la presencia y estado de la flora chilena emparentada con cultivos genéticamente modificados, con énfasis en el riesgo de flujo génico. Informe Final proyecto UNEP_GEP_CONAMA "Desarrollo de un marco nacional de bioseguridad para Chile." CONAMA.

Nap, J.P., P.L.J. Metz, M. Escaler, and A.J. Conner. 2003. The release of genetically modified crops into the Environment. Part I. Overview of current status and regulations. The Plant Journal 33: $1-18$.

NCBI. 2009. National Center for Biotechnology Information. Available online at: http://www.ncbi. nlm.nih.gov/

O' Callagan, M., T.R. Glare, E.P.J. Burgess, and L.A. Malone. 2005. Effects of plants genetically modified for insect resistance on nontarget organisms. Annual Review of Entomology 50: 271-292.

Pardo H, G. 2006. Marco regulatorio en Chile para cultivos genéticamente modificados. En Seminario Internacional sobre Organismos Genéticamente Modificados (GMOS) y el Mercado Europeo. Servicio Agrícola y Ganadero (SAG), 
Santiago, Chile. 199 p.

Prieto, H. 2006. Proyecto Desarrollo de un sistema de trazabilidad molecular y de evaluación del impacto sobre la biodiversidad local de plantas genéticamente modificadas a través de transgenia. En Seminario Internacional sobre Organismos Genéticamente Modificados (GMOS) y el Mercado Europeo. Servicio Agrícola y Ganadero (SAG), Santiago, Chile. 199 p.

Prieto, H. 2009. Plataformas de transformación genética en frutales. Tierra Adentro 85: 30-31.

Redenbaugh, K., M. Hiatt, B. Martineau, M. Kramer, R. Sheehy, R. Sanders, C. Houck, and D. Emlay. 1992. Safety Assessment of Genetically Engineered Fruits and Vegetables; a Case Study of the FLAVR SAVRTM Tomato. Boca Raton, FL: CRC Press.

Romeis, J., M. Meissle, and F. Bigler. 2006. Transgenic crops expressing Bacillus thuringiensis toxins and biological control. Nature Biotechnology 24: $63-71$.

SAG. 2009. Organismos Vegetales Vivos Modificados (OVVM). Available online at: http://www. sag.cl/openDocs/asp/pagVerRegistro.asp?boto $\mathrm{n}=$ Doc5 1 \& $\arg$ InstanciaId $=51$ \&argCarpetaId= $324 \& \arg$ TreeNodosAbiertos $=(324)(-51) \& \arg$ TreeNodoActual $=324 \& \arg$ TreeNodoSel=-51 \&argRegistroId $=1514$

Sasson, A. 2006. Plant and agricultural biotechnolo- gy. Achievments, prospects and perceptions. Coordinación de Ciencia y Tecnología, De Nuevo León, México. 444 p.

Sanders, R., and W. Hiatt. 2005. Tomato transgene structure and silencing. Nat Biotechnol 23 (3): 287-9.

Schouten, H.J., and J. Evert. 2008. Cisgenesis and intr, sisters in innovative plant breeding. Trends in Plant Science 13(6):260-261.

Schuler, T.H., R.P.J. Pottingg, I. Denholm, and G.M. Poppy. 1999. Parasitoid behavior and Bt plants. Nature 400: 825-829.

Wang, Y., B. Chen, Y. Hu, J. Li, and Z. Lin. 2005. Inducible excision of selectable marker gene from transgenic plants by the Cre/lox site-specific recombination system. Transgenic Research 14: 605-614.

Wolfenbarger, L.L., and P.R. Phifer. 2000. The Ecological Risks and Benefits of Genetically Engineered Plants. Science 290 (5499): 2088 - 2093.

Ye, X, S. Al-Babili, A. Klöti, J. Zhang, P. Lucca, P. Beyer, and I. Potrykus. 2000. Engineering provitamin A ( $\beta$-carotene) biosynthetic pathway into (carotenoid-free) rice endosperm. Science 287: 303-305

Yonekura-Sakakibara, K., and K. Saito. 2006 Review: genetically modified plants for the promotion of human health. Biotechnol Lett. 28:1983-1991. 